\title{
ASSESSMENT OF A URBAN SUSTAINABILITY AND LIFE QUALITY INDEX FOR ELDERLY
}

\author{
D. ASTIASO GARCIA ${ }^{1}$, F. CUMO ${ }^{2}$, E. PENNACCHIA ${ }^{1}$, V. STEFANINI PENNUCCI ${ }^{3}$, \\ G. PIRAS ${ }^{1}$, V. DE NOTTI ${ }^{2} \&$ R. ROVERSI ${ }^{2}$ \\ ${ }^{1}$ DIAEE (Department of Astronautic, Energetic and Electric engineering), Sapienza University of Rome, Italy. \\ ${ }^{2}$ CITERA, Interdepartmental Centre for Territory, Building, Conservation and Environment, \\ Sapienza University of Rome, Italy. \\ ${ }^{3}$ Department of Planning, Design, and Technology of Architecture, Sapienza University of Rome, Italy.
}

\begin{abstract}
The research here presented originates from some of the ongoing challenges of our society: the demographic changes and the high share of population living in urban areas. The aim of the research is the definition of an index of sustainability and quality of life for elderly at suburban scale, not only able to outline aspects related to the local territorial context but also to represent the neighbourhood level. This would provide significant added value to existing indicators that represent the quality of life for much larger areas as cities, regions and nations. Indeed, it is universally recognised that the quality of life varies quite considerably depending on whether you live in different neighbourhoods or urban areas.

The index proposed with the research is elaborated on the base of objective and subjective indicators integrated with the judgment of experts, in order to give an accurate and truthful weight to each indicator. Moreover, it has been elaborated for microscale analysis, dividing urban areas into cells, in order to highlight more in detail the real needs of each specific zone.

As a result, the elaborated index would be an available tool to be provided to the local public administration to facilitate and optimise the urban planning and management, prioritizing interventions on the base of the sustainability principles and subjective needs of the population, in particular of elderly. Keywords: ageing society, built environment, urban cell, urban sustainability index.
\end{abstract}

\section{INTRODUCTION}

Although ageing is a global phenomenon, Europe is already the oldest continent [1]. In the Strategic Research Agenda of the Joint Programming Initiative (JPI) More Years, Better Lives - The potentials and Challenges of Demographic Change, it is underlined that the demographic change underway is modifying the shape of Europe. In particular, while the size of population remains stable, the average age of the population is steadily rising, due to increasing life expectancy, low fertility rates and complex patterns of migration. In the last 20 years, the median age of the European population rose by $12 \%$ and it is projected an increase of $16 \%$ by 2060 . At the same time, the proportion of people over 65 years rose by $27 \%$, while the proportion aged over 80 years is growing rapidly [2]. In Europe, in less than four decades, over a third of the total population is projected to be above 60 years of age and the ratio of persons aged 65 or older compared with the working age population is thus expected to rise strongly [3]. The ageing of populations will entail many challenges due to the growing pressures on different aspects related to society as economic performance, social and health care and public finances. The deterioration of mental and physical capacity has become a challenge of society at international level, especially due to dementia and Alzheimer's diseases [4]. At the same time, innovative technologies have been adopted in the last years for the improvement of the health of elderly people [5]. In the long-term prospects, it is essential that older population stays healthy, independent, active and involved in families life, society and economy as long as possible. OECD studies affirm that science 
and technology, and particularly ICT applications, are focal themes to achieve these societal goals [6].

It has been stated that solutions to the challenge of the impact of population ageing on our standard of living in the future could be: tools to raise labour force participation at older ages and bridge employment. To these considerations must be added that 'today more than half the world population lives in cities' [8]. According to the World Health Organization (WHO) [9], in 1960 , the urban population was $34 \%$ of the world total and in 2014, this percentage is increased to $34 \%$. This figure is constantly increasing; the growth is expected to be of about $1.84 \%$ per year, between 2015 and 2020, 1.63\% per year, between 2020 and 2025 and $1.44 \%$ per year, between 2025 and 2030 .

In 2015 , about $10 \%$ of the global population ( 7349 millions) lived in Europe ( 738 million), the European population is projected to decrease between 2015 and 2050 [10]. Urban dwellers are the majority, around $75 \%$, of the European population and urban areas are expanding across Europe with more citizens that are moving from the city centres, but urbanisation is not a simple process, the drivers of it are multiple and often interrelated, as ageing, migration or trend to smaller and more households [11].

Cities are areas that concentrate people, opportunities and solutions but at the same time condense challenges and difficulties. Elderly are particularly vulnerable to the impacts produce by an urban area. As stated in the Italian Position Paper Moving forward for an Ageing Society: Bridging the distance, [12], the increase of the elderly population entails that our society adopts a new approach. The reduction of the physical and virtual distances is a major societal challenge: for example, the distances between places of residence, employment and services; social, economic and cultural distances; distances between different generations or material and spiritual needs. The re-establishment of the appropriate distances, while preserving the necessary interconnections, is the key strategy to guarantee the societal resilience from the effect of ageing population. It is an opportunity to our society to grow as a whole. The research presented in this article arises from the abovementioned Italian Position Paper, and in particular, it examines one of the four priority areas identified in the document: the built environment. The aim of the research is to elaborate a new method for assessing life quality of elderly at suburban scale, integrating objective indicators, coming from statistical data, and subjective indicators, taking into account both the opinions of experts and elderlies. Although many life quality indices have been elaborated in literature, most of them are not specifically related to the elderly. A significant example of quality-of-life index is the Global Age Watch Index [13] which, however, defines a national framework of the older populations. In this context, the paper first highlights what are the main themes that could influence life quality of elderlies in urban areas and then, after a brief analysis of the state of the art about this topic, a new methodology for assessing life quality of aged people in cities will be presented. The last part of the paper will provide a discussion of the results obtained by testing the methodology presented.

\section{ESSENTIAL FEATURES FOR AGE-FRIENDLY CITIES}

The ongoing significant demographic changes imply the need for a rethinking of the city in terms of greater protection of vulnerable groups of the population in order to achieve satisfactory levels of life quality. It is important to consider the connection between environment and older people in order to balance the physical and social changes associated with ageing within a flexible and evolving environment [14]. The urban living is the prevalent social framework 
for most of the world's population, and it has the ability and strength to shape many factors within populations [15].

The creation of age-friendly cities has been promoted by the WHO as a fundamental strategy to address the challenges posed by the combining trends of demographic changes and urbanisation [16]. As stated by Fadda et al. [17], space and territory are the basis of social networks that generate collective and individual age group identities.

It is proved that age-friendly initiatives in the social and physical environment and stakeholder collaborations are essential elements that will facilitate the creation of a mutually enhancing environment for older people [18]. In 2007, the WHO published a Guide for Global Age-friendly Cities. Age-friendly cities are defined as places that allow people of all ages to participate in community activities, to be treated with respect, and where who can no longer take care of themselves can find help in order to have a satisfying and decent life. The WHO has defined the term 'active ageing' as the process of optimizing opportunities for health, participation and security in order to enhance quality of life as people age [19]. As stated by the WHO [20], an age-friendly city considers elderly people as sources of capacity and resources, thus actively it involves and support older people through policies, services and facilities in order to enhance their quality of life. In broad terms, an age-friendly city should: anticipate, respect and take into account the needs, preferences and decisions of older people; protect the most vulnerable citizens; encourage their inclusion and active participation to community life. The WHO's Guide proposes and analyses eight topics related to active ageing covering the features of the city's structures, environment, services and policies that condition the senior citizens' quality of life. Outdoor spaces, buildings and transportation concern the physical environment, while social participation, respect/social inclusion, civic participation and employment, communication/information and community support/ health services are determinant for the mental well-being, for the definition of the opportunities offered by the social environment and also for the economic implications [20]. The WHO Guide defines a framework for making informed choices and for developing flexible community assessment tools that can be tailored and adapted to local circumstances: a needs assessment identifies the gaps in and opportunities for improving a community's age-friendliness and involves identifying the tools that you will use to collect the information, such as surveys, focus groups or questionnaires. The collected information is aimed at developing an action plan or a road map that will guide the community's age-friendly planning.

The present research elaborates a checklist on the base of the WHO age-friendly cities recommendations, integrating it into a methodology for the definition of a urban sustainability and life quality index for elderly (see Section 4).

\section{STATE OF THE ART}

The background of this research concerns two main areas of intervention: quality of life and urban environments, connected by a common subject of interest, the elderly. The main and most significant initiatives in Europe related to these aspects are three Joint Programming Initiatives (JPI). The JPI 'More Years Better Lives, The potentials and Challenges of Demographic Change' that is based on a transnational and multi-disciplinary approach in order to find solutions and opportunities from the underway demographic change. It envisages five working groups on the issues: health and performance; welfare and social systems; work and productivity; education and learning; housing, environment and mobility. Furthermore, it explores four overlapping domains: quality of life, health and well-being; 
economic and social production; governance and institutions; sustainable welfare. The JPI called 'Neurodegenerative Disease Research' that faces the challenge of neurodegenerative diseases. The purpose of this JPI is to find causes, develop cures and appropriate ways to care, with the aim of give a boost to the definition of solutions to reduce the symptoms of the disease and the social and economic impact for patients, families and healthcare systems. Finally, the JPI 'Urban Europe' that arises from the need to contrast the challenges related to urban areas that society will face. The aim of the JPI 'Urban Europe' is to create attractive, sustainable and economically feasible urban areas. In particular, it promotes the transformation of urban areas into centres of innovation, sustainability and technology, with intelligent transport and logistic systems, promoting social cohesion and integration, the reduction of the ecological footprint and the climate neutrality. In 2014, the Committee of Ministers of EU Member States adopted a recommendation on the promotion of human rights of older persons, the purpose of which is to promote, protect and ensure the full and equal enjoyment of all human rights and fundamental freedoms by all older persons and to promote respect for their inherent dignity [21]. In the Recommendation, it is stated that elderly representative organisations should be consulted in case of adoption of measures that have an impact on the enjoyment of their human rights. A significant European ongoing project is The Dublin City Age-Friendly Strategy 2014-2019: it is conceived as an answer to the 'Declaration on Age-friendly Cities and Communities in Europe' signed in Dublin by the EU representatives in 2013. The Dublin Declaration frames, the commitment to meet the needs of the increasing elderly population through a more inclusive community and urban environment sharing principals, values and approaches. The Dublin municipality is actuating the strategy, composed by nine objectives and five action plans [22]. The Swedish Symbio City is a conceptual scenario aimed at the urban sustainable development through the promotion of a holistic, integrated and multidisciplinary method to be applied by cities that want to create quarters. The quality of life of citizens, especially the most fragile, is the ultimate goal at the centre of the model, including health, comfort and safety [23]. More focused on the residential needs of the elderlies is the work of the International Longevity Centre and Habitneg Housing Association (United Kingdom): they are developing and experimenting design criteria to build age-friendly houses and urban environments [24]. At national level is important and significant the Italian Position Paper Moving Forward for an Ageing Society: Bridging the Distances, which illustrates the harmonisation of technology and humanity, and the reduction of scale of the community, in order to induce it to perceive the real needs of citizens, ensuring the resilience of our society to the ageing population. In addition, a unique project in the world is the 'Train the brain' project of the Italian National Research Council, realised by prof. Maffei. This initiative has the purpose of verifying the ability of adequate brain stimuli, such as physical and intellectual activities, to change the course of the most common neurodegenerative diseases. Nayolor et al. [25] and Sun et al. [26] highlighted the importance of analysis of both objective factors (as health status, behavioural and social-psychological aspects that are objectively and statistically measurable) and subjective factors (as the perceived ones) for assessing quality of life of elderly people. In addition, Yung et al. [27] affirmed that the planning of public open spaces in urban renewal districts should address the special social needs of the relatively concentrated elderly population. Finally, a Significant Bilateral Project about sustainable quality of life in urban areas is the So.UR.CE. (Sustainable Urban Cells) project, which was approved within the Executive Programme on Scientific and Technological Cooperation between the Italian Republic and the Kingdom of Sweden and financed by the Italian 
Ministry for Foreign Affairs jointly with the Ministry of Education, Universities and Research. The purpose of the So.UR.CE. project was to develop guidelines and policies at microscale level (urban cell), in order to rethink the urban areas and the integrated design of building systems, with the goal of energy saving and environmental sustainability, in order to improve the quality of life of all citizens, including the elderlies [28]. The theoretical model and methodology developed by the project have been translated into operational tools for the public administration providing concrete support to the process of planning, financing and implementation of measures needed to improve the quality of life and environmental sustainability in urban areas [29,30], with particular regard to natural protected areas [31-33]. The studies on age-friendly cities and communities have given rise to researches that have mainly produced a range of descriptive strategies or practices, but there is a lack of documentation on the effectiveness of these approaches [18]. The evaluation of age-friendly initiatives can be facilitated by the availability of tools based on indicators through tracking and benchmarking [34].

\section{METHODOLOGY FOR THE DEFINITION OF A URBAN SUSTAINABILITY AND LIFE QUALITY INDEX FOR ELDERLY}

The main philosophical approaches to quality of life define the good life differently: (1) religious or philosophical norms; (2) satisfaction of preferences; (3) subjective well-being [35]. The expression quality of life is used by most persons as goodness of life within the environment [36], but the standard indicators of the quality of life are related to all the aspects of life as wealth, employment, built environment, health, education, recreation and leisure time, and social belonging [37]. Many disciplines have adapted the definition of quality of life to their research domain, but the understanding about it should be extended and integrated to other disciplines because it is a multifaceted concept [38]. In this paper, quality of life is considered as dependent on the fulfilment of material and intangible needs [12]. Both categories include basic needs that must be met in order to guarantee at least the minimum standards of quality of life, considering physical and mental components [26]. Taking into account such aspects, it is possible to give an objective evaluation of the quality-of-life levels. However, at the same time, the concept in question has a significant subjective component, since it is the individual who establish, according to his own judgment, what makes his own life pleasant, rewarding and satisfying. In particular, in order to enhance their quality of life, aged people need to live in urban areas with services, initiatives and features for optimizing their health, security perception and perceived well-being [25, 27].

Therefore, the elaborated index includes: objective indicators, statistical and literature data about the analysed areas; subjective indicators, obtained asking opinions to the elderly about their needs and priorities; judgement of experts, whose expertise is needed for giving a truthful weight to each indicator [39]. Moreover, an added value of the index is that it is elaborated for microscale analysis, dividing urban areas of interest into urban cells [28] in order to highlight real needs of each specific subzone. In particular, the elaborated Life Quality Index (LQI) derives from the average value of the subindices described in the following subparagraphs: OII, the Objective Indicators Index and SII, the Subjective Indicators Index, as reported in eqn (1).

$$
L Q I=(O I I+S I I) / 2
$$




\subsection{Objective indicators analysis}

A first analysis took into account the main objective indicators, whose values are available in official databases at microscale [40], considering five broad areas (quality of life; business and labour; services and environments; population and leisure) included in two main streams: elderly quality of life and key features of urban environment. For each of the two main aspects, the indicators essential to consider have been selected in order to make an urban area age friendly as housing, climate, structures, urban green areas, recycling, population density and birth rate (Table 1). The indicators analysed in the research were selected from a set of objective indicators used nationally to assess the quality of life in urban areas [40], on the base of a set of parameters considered fundamental to evaluate the age friendliness of a city [20]. In details, we started to elaborate the methodology proposed analysing indicators that are referred to the quality of life and to the total population. Later, we took into account the main topics developed by WHO [20], whose assessment is necessary to make a city an age-friendly city, in order to consider only the parameters significant for an age-friendly urban area.

In addition, for each indicator, it was evaluated the percentage change (PC, Table 1) to eliminate the different weight of any indicator due to the different unit of measurement as well as the different order of magnitude. It has been calculated comparing the values of each parameter with the national average of the same indicators (eqn (2), where 'lo' and 'hi' indicate the lower and the higher values, respectively).

$$
P C=100-\frac{l o \cdot 100}{h i}
$$

As used by authors in a previous similar research [41], the final score varies between -3 and +3 depending on the positive or negative change compared to the national average (positive values when the situation in the urban cell is better than the national average). This approach allows to eliminate the differences coming from the different order of magnitude of each considered parameter. It is necessary to evaluate the national average in order to make a comparison between different urban areas and to identify the major criticalities of a specific zone considered. If the variation is greater than $15 \%$ will be assigned the value \pm 3 , depending on whether the situation of the urban cell is better or worse than the national average. For variations from 10 to $15 \%$, the score will be \pm 2 , from 5 to $10 \%$ it will be equal to \pm 1 , while for variations below 5\%, the final score will be zero. As reported in eqn (3), the OII has been obtained standardizing in a range from -100 to 100 the sum of each indicator final score, according with three previous studies $[42,43]$ where different indicators have to be compared for the elaboration of a final single index which includes different parameters.

$$
O I I=100 \cdot \frac{\sum_{i=1}^{i=16} \text { scores }}{\left[\sum_{i=1}^{i=16} \text { scores }\right]_{\max }}
$$

\subsection{SII - Subjective indicators analysis}

The analysis of subjective indicators consist in a double scale analysis plus experts opinions. It includes 14 indicators that are submitted to the judgment of the elderly population of the 
Table 1: scheme for a calculation of the OII in a pilot urban cell.

\begin{tabular}{|c|c|c|c|c|c|}
\hline & & $\begin{array}{l}\text { Pilot } \\
\text { urban } \\
\text { cell }\end{array}$ & $\begin{array}{l}\text { National } \\
\text { average }\end{array}$ & $\begin{array}{l}\text { Percentage } \\
\text { change }\end{array}$ & $\begin{array}{c}\text { Score } \\
(\text { from } \\
-3 \text { to }+3)\end{array}$ \\
\hline & $\begin{array}{l}\text { Working age population / } \\
\text { elderly population }(\%)\end{array}$ & 57,00 & 47,30 & 17,0 & 3 \\
\hline & $\begin{array}{l}\text { Climate - Annual thermal } \\
\text { excursion }\left({ }^{\circ} \mathrm{C}\right)\end{array}$ & 16,00 & 22,39 & $-28,5$ & 3 \\
\hline & $\begin{array}{l}\text { Health - Hospital emigration } \\
\text { rate }(\%)\end{array}$ & 100,00 & 9,20 & $-90,8$ & -3 \\
\hline & $\begin{array}{l}\text { Population density of urban } \\
\text { areas (inhabitants } / \mathrm{km}^{2} \text { ) }\end{array}$ & $1.555,00$ & $2.220,00$ & 42,8 & 3 \\
\hline \multirow[t]{5}{*}{$\begin{array}{l}\text { Elderly } \\
\text { quality of life }\end{array}$} & $\begin{array}{l}\text { Birth-rate (births per } 1,000 \\
\text { people) }\end{array}$ & 10,20 & 8,63 & 15,4 & 3 \\
\hline & $\begin{array}{l}\text { Young people (\% of aged } \\
\text { under } 25)\end{array}$ & 28,00 & 25,30 & 9,6 & 1 \\
\hline & $\begin{array}{l}\text { Bookshops (per 1,000 } \\
\text { people) }\end{array}$ & 0,00 & 0,08 & 100,0 & -3 \\
\hline & $\begin{array}{l}\text { Events and shows } \\
\text { (per } 1,000 \text { people) }\end{array}$ & 98,00 & 63,63 & 35,1 & 3 \\
\hline & $\begin{array}{l}\text { Restaurants and coffee shops } \\
\text { (per 1,000 inhabitants) }\end{array}$ & 7,20 & 6,15 & 14,6 & 2 \\
\hline \multirow{8}{*}{$\begin{array}{l}\text { Key features } \\
\text { of the urban } \\
\text { environment }\end{array}$} & House price $\left(€ / \mathrm{m}^{2}\right)$ & $2.600,00$ & $2.165,89$ & 16,7 & 3 \\
\hline & Broadband coverage $(\%)$ & 100,00 & 92,11 & 7,9 & 1 \\
\hline & $\begin{array}{l}\text { Cycle paths (meters per } \\
1,000 \text { inhabitants) }\end{array}$ & 0,00 & 41,60 & 100,0 & -3 \\
\hline & Charging stations managers & 0,00 & 1,00 & 100,0 & -3 \\
\hline & Recycling (\%) & 38,00 & 33,40 & 12,1 & 2 \\
\hline & $\begin{array}{l}\text { Facilities for children } \\
\text { (municipal crèches } \\
\text { per } 10,000 \text { inhabitants) }\end{array}$ & 2,00 & 1,74 & $-14,9$ & 2 \\
\hline & $\begin{array}{l}\text { Urban green areas } \\
\left(\mathrm{m}^{2} \text { per inhabitant }\right)\end{array}$ & 58,00 & 106,40 & 45,5 & -3 \\
\hline & Total scores & & & & 11 \\
\hline
\end{tabular}


analyzed urban cell. The methodology foresees that a sample of retired people that live in the analyzed urban cell assign for each indicator a value of satisfaction. In particular, it was asked to a statistically significant number of retired people to attribute two different weights to each indicator with reference to the urban cell where they live: a satisfaction degree, ranging from -3 to +3 , called ' $E$ ' Subjective Evaluation, and a value of Subjective Importance (Is), ranging from 0 to 5 . The feedback on the citizens satisfaction (E) are computed in the final index without any alteration while it is necessary reflect on the section related to the importance and weights to be assigned to each of the 14 indicators. In fact, it is well known that there are different criterion of allocation of weights to the parameters; it is possible, for example, rely solely on the judgment of users (risking to elaborate a subjective assessment limited to personal experiences) or on the evaluation carry out by a pool of technicians and scientists (getting more balanced values but with the possibility to not represent the sensitivity of local users). Considering the two options described above, in the presented research it was chosen to adopt a methodology able to take into account both components, attributing averaged weights called 'Iw' (Weighted Importance) obtained considering to the same extent the views expressed by the experts and those resulting from the submission of questionnaires to the elderlies (Table 2). Each Individual Evaluation Index (IEI) was obtained standardizing from -100 to 100 the products of $\mathrm{E}$ and Iw, using the same approach of eqn (3). Then, by means of the same standardisation method, the global Subjective Indicator Index (SII) was obtained standardizing from -100 to 100 the sum of each IEI, as reported in eqn (4).

$$
S I I=100 \cdot \frac{\sum_{i=1}^{i=13} I E I_{i}}{\left[\sum_{i=1}^{i=13} I E I\right]_{\max }}
$$

\subsection{LQI - Life quality index assessment}

For each analysed suburban area, according to eqn (1), the overall Life Quality Index (LQI) derives from the average values of the objective (OII) and subjective (SII) indicators indexes. Therefore, in order to integrate these different values, the total scores of OII and SII have been standardised in a range from -100 to 100 , with the values of \pm 100 assigned to the highest or lowest possible value. In particular, these standardisations have been calculated as reported in eqns (3) and (4).

\section{FIELDS OF APPLICATION AND CASE STUDIES EXPECTED IN FUTURE}

This methodology was designed for a microscale analysis, in order to have an index for each urban cell. An urban cell is an elementary form of territory within which plan, design, implement and manage the interventions of urban, energetic, natural resources and socioeconomic redevelopment [28]. The subdivision of an area in urban cells allows to analyse the needs of the elderly people at suburban microscale in order to identify local intervention for improving their quality of life; moreover, it permits to design interventions in small portions of the city comparing life quality indices and criticalities of different zones of the same city.

The quality of life depends on whether you live in a major European city, even more so if we consider distinct urban areas forming part of the same Province. 
Table 2: Scheme for a calculation of the SII in a pilot urban cell.

\begin{tabular}{|c|c|c|c|c|c|c|}
\hline Macroareas & & $\begin{array}{c}\text { E subjective } \\
\text { evaluation } \\
\text { (from } \\
-3 \text { to }+3)\end{array}$ & $\begin{array}{c}\text { Is } \\
\text { subjective } \\
\text { importance } \\
\text { (from } \\
0 \text { to 5) }\end{array}$ & $\begin{array}{l}\text { Ie expert } \\
\text { importance } \\
\text { (from } \\
0 \text { to 5) }\end{array}$ & $\begin{array}{c}\text { Iw } \\
\text { weighted } \\
\text { importance } \\
\text { (from } \\
0 \text { to 5) }\end{array}$ & E x Iw \\
\hline \multirow{7}{*}{$\begin{array}{l}\text { Elderly } \\
\text { quality } \\
\text { of life }\end{array}$} & $\begin{array}{l}\text { Safety and security } \\
\text { perception }\end{array}$ & 1 & 5 & 5 & 5.0 & 5.00 \\
\hline & Purchasing power & 0 & 4 & 3 & 3.5 & 0.00 \\
\hline & $\begin{array}{l}\text { Family } \\
\text { relationships } \\
\text { satisfaction }\end{array}$ & 3 & 5 & 5 & 5.0 & 15.00 \\
\hline & $\begin{array}{l}\text { Social relationships } \\
\text { satisfaction }\end{array}$ & -1 & 3 & 4 & 3.5 & -3.50 \\
\hline & $\begin{array}{l}\text { Healthcare } \\
\text { satisfaction }\end{array}$ & -2 & 5 & 4 & 4.5 & -9.00 \\
\hline & $\begin{array}{l}\text { Satisfaction of } \\
\text { basic needs services } \\
\text { (supermarket, } \\
\text { pharmacy, etc.) }\end{array}$ & 0 & 5 & 4 & 4.5 & 0.00 \\
\hline & $\begin{array}{l}\text { Services for } \\
\text { culture and } \\
\text { leisuresatisfaction }\end{array}$ & 1 & 2 & 3 & 2.5 & 2.50 \\
\hline \multirow{7}{*}{$\begin{array}{l}\text { Key features } \\
\text { of the urban } \\
\text { environment }\end{array}$} & $\begin{array}{l}\text { Travels and } \\
\text { holidays }\end{array}$ & 2 & 1 & 3 & 2.0 & 4.00 \\
\hline & $\begin{array}{l}\text { Perception of } \\
\text { urban green }\end{array}$ & -2 & 2 & 3 & 2.5 & -5.00 \\
\hline & $\begin{array}{l}\text { Satisfaction of } \\
\text { accessibility of } \\
\text { places }\end{array}$ & -1 & 3 & 3 & 3.0 & -3.00 \\
\hline & $\begin{array}{l}\text { Satisfaction of } \\
\text { urban traffic }\end{array}$ & -3 & 3 & 2 & 2.5 & -7.50 \\
\hline & $\begin{array}{l}\text { Public transport } \\
\text { satisfaction }\end{array}$ & 1 & 2 & 3 & 2.5 & 2.50 \\
\hline & $\begin{array}{l}\text { Dwelling } \\
\text { liveability and } \\
\text { comfort }\end{array}$ & 0 & 2 & 3 & 2.5 & 0.00 \\
\hline & Total score & & & & & 1.00 \\
\hline
\end{tabular}


The developed methodology can be applied to any urban areas of different size (number of inhabitants) because each reference territory is divided into urban cells.

The urban cells are areas characterised by homogeneous characteristics (social, environmental, cultural, economic, demographic) with a population density of between 1500 and 3000 inhabitants.

As case study, we have analysed the following Italian municipalities: Trevignano (5000 inhabitants); Ladispoli (50,000 inhabitants, Fig. 1); Rimini (100,000 inhabitants); Florence (380,000 inhabitants); Rome (3,000,000 inhabitants).

As tested in other research studies about environmental management and impact factors analysis of the same research team [44-47], GIS software will be used for the elaboration geographic databases useful for identifying areas characterised by critical values. As regards the number of persons interviewed, we have considered a sample of 130 people for each municipality. This number was determined on the base of two aspects: the sample size was of 600 residents in each of the 107 provinces in the research on the index of quality of life elaborated by Il Sole 24 ore [48]; considering the year 2015 the Italian population over the age of 65 is the $21.7 \%$ of the total population [40].

\section{CONCLUSIONS AND FURTHER DEVELOPMENT}

This study's main objective was to help broaden the knowledge of the condition of older people by providing a tool to detect it and support the identification of interventions, aimed to higher levels of well-being of the elderly. The review of the literature on age-friendly initiatives, concerning the social and physical environment, demonstrates that multi-stakeholder collaborations are important factors that will help to build a mutually enhancing environment

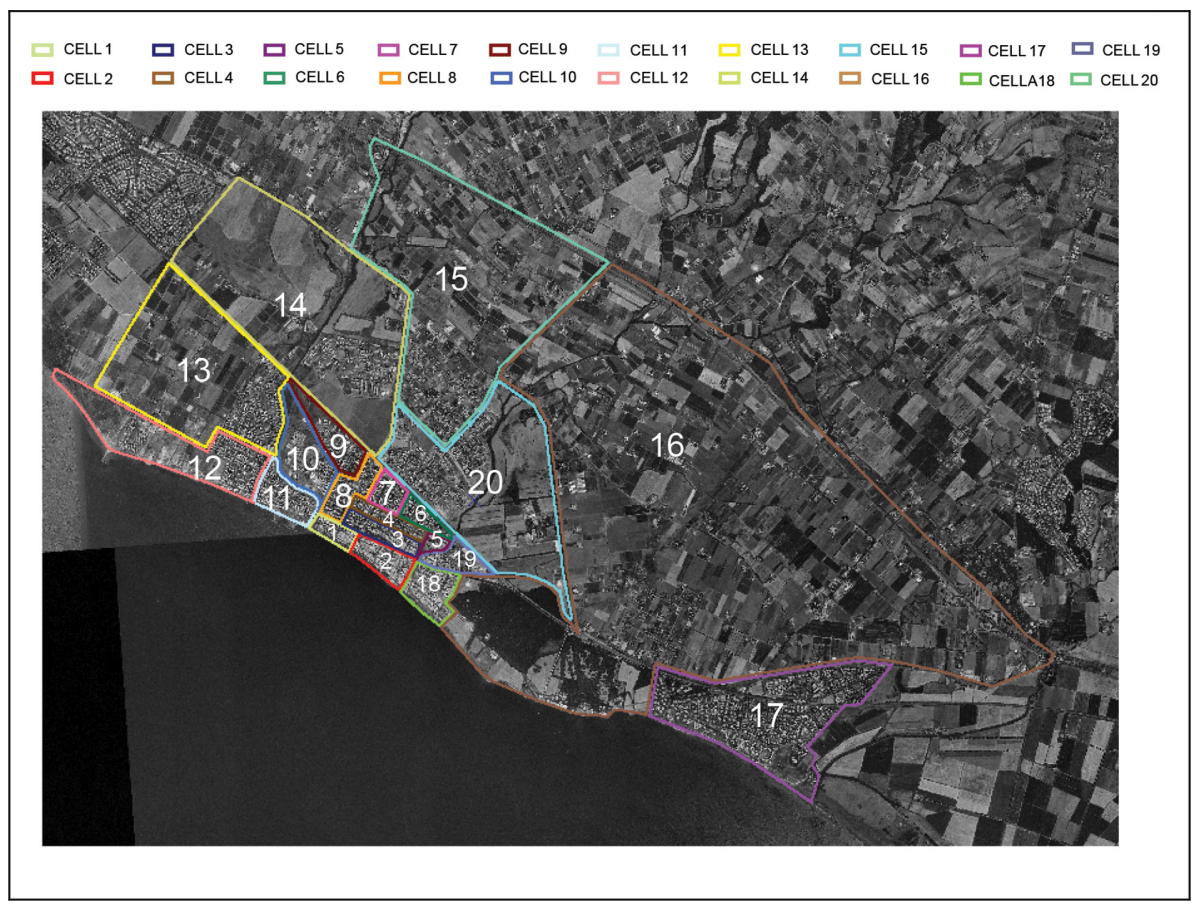

Figure 1: urban cells delimitation in Ladispoli town. 
for older people [18]. In particular, city planners, policy makers and research institutions should be encouraged to take a proactive approach and engage with the older people themselves to create age-friendly cities. The first goal is the knowledge of their current quality of life and their needs in order to develop specific initiatives. It is particularly important to consider the cultural and socio-economic influences of the ageing local population when determining measures, programs and activities.

The use of indicators was recommended in the literature as a way of collecting expectations and evaluating the principals deficiencies in urban environments. Indicators are also helpful to assess outcomes and effectiveness of interventions and activities [48, 49]. In the setting of investigations and age-friendly interventions, the most part of researches and experiences are limited to small older person communities in small towns or districts of a city or they consider the city as whole, ignoring that they are a diverse mix of communities including different social, cultural, economic and ethnic groups. Moreover, cities are composed by various zones with their own physical characteristics and different level of quality of life. Through the aggregation of several urban cells, basic modules in which is divided a city, it is possible to take into account the specific needs and features of a limited urban area and, after the combination, outline a general overview of the city, in order to develop programs involving different scales. Next steps of this research are: carry out interviews to privileged witnesses, submit to elderly in the above urban contexts a specific questionnaire to fill in, collect data and elaborate the results. Urban planning represent definitely one of the most significant areas of use of social indicators, and, to be qualified as sustainable, it must take into equal consideration economy, society and environment through an integrated approach. The proposed life quality index can be a tool to provide to local public administrations in order to plan the management of their areas by organizing interventions on the basis of the subjective and objective needs of the elderly population. Further research that considered different communities and different urban environments would allow decision and policy makers to explore how ageing affects these settlements and whether age-friendly interventions need to be adjusted to ensure success.

\section{ACKNOWLEDGEMENTS}

This research was carried out within the significant bilateral project PRACTICE (Planning Rethinked Ageing Cities Through Innovative Cellular Environments), financed by the Italian Ministry for Education, Universities and Research (MIUR) under the Executive Programme on Scientific and Technological Cooperation between Italian Republic and the Kingdom of Sweden for the years 2014-2016.

\section{REFERENCES}

[1] Neyer, G., Andersson, G., Kulu, H., Bernardi, L.\&Bühler, C. (eds), The Demography of Europe, Springer, 2013.

[2] Eurostat, Active Ageing and Solidarity Between the Generations: a Statistical Portrait of the European Union, 2012, Publications Office of the European Union: Luxembourg, 2011.

[3] Cuaresma, J.C., Loichinger, E. \& Vincelette, G.A., Aging and income convergence in Europe: A survey of the literature and insights from a demographic projection exercise. Economic Systems, 40(1), pp. 4-17, 2016. http://dx.doi.org/10.1016/j.ecosys.2015.07.003 
[4] EU Joint Programme. Neurodegenerative Disease Research, Why choose neurodegenerative diseases?available at: http://www.neurodegenerationresearch.eu/about/why/

[5] Jouin, M., Gouriveau, R., Hissel, D., Péra, M.C. \& Zerhouni, N., Degradations analysis and aging modeling for health assessment and prognostics of PEMFC.Reliability Engineering \& System Safety, 148, pp. 78-95, 2016.

http://dx.doi.org/10.1016/j.ress.2015.12.003

[6] OECD, OECD Science, Technology and Industry Outlook 2014, OECD Publishing: Paris, 2014.

[7] Smaliukiene, R. \& Tvaronaviěienè, M., Bridge employment: an opportunity for aging society.19th International Scientific Conference, Procedia - Social and Behavioral Sciences, 156, pp. 388-391, 2014.

http://dx.doi.org/10.1016/j.sbspro.2014.11.208

[8] United Nations, World's Population Increasingly Urban with More Than Half Living in Urban Areas, UN: New York, 2014.

[9] World Health Organization, Global Health Observatory data, World Health Organization: Geneva, 2014.

[10] United Nations, World Population Prospects - The 2015 Revision, UN: New York, 2015.

[11] European Environment Agency, Ensuring quality of life in Europe's cities and towns, EEA Report No 5/2009, Copenhagen, 2009.

[12] Presidenza Italiana del Consiglio dell'Unione Europea e Ministero dell'Istruzione, dell'Università e della Ricerca. Moving forward for an Ageing Society: Bridging the Distances, Italian position paper, Palombi: Roma, 2014.

[13] Global AgeWatch Index 2015, available at: http://www.helpage.org/global-agewatch/

[14] Beard, J.R. \& Petitot, C., Ageing and urbanization: Can cities be designed to foster active ageing? Public Health Reviews, 32, pp. 427-450, 2010.

[15] Galea, S. \& Vlahov, D., Urban health: Evidence, challenges, and directions.Annual Review of Public Health, 26, pp. 341-365, 2005.

http://dx.doi.org/10.1146/annurev.publhealth.26.021304.144708

[16] World Health Organization, Health 2020: a European Policy Framework Supporting Action across Government and Society for Health and Well-Being, World Health Organization: Geneva, 2012.

[17] Fadda, G., Cortés. A., Olivi, A. \& Tovar, M., The perception of the values of urban space by senior citizens of Valparaiso. Journal of Aging Studies, 24, pp. 344-357, 2010. http://dx.doi.org/10.1016/j.jaging.2010.07.001

[18] Steels, S., Key characteristics of age-friendly cities and communities: A review.Cities, 47, pp. 45-52, 2015.

http://dx.doi.org/10.1016/j.cities.2015.02.004

[19] World Health Organisation, Active Ageing: a Policy Framework. World Health Organisation: Geneva, 2002.

[20] World Health Organisation, Global Age-friendly Cities: A Guide, World Health Organisation: Geneva, 2007.

[21] Council of Europe. Recommendation CM/Rec(2014) of the Committee of Ministers to Member States on the Promotion of Human Rights of Older Persons, Council of Europe: Bruxelles, 2014.

[22] Dublin Municipality, Dublin city Age Friendly Strategy 2014-2019, Dublin, 2014.

[23] Ranhagen, U. \& Groth, K., The Symbio City Approach, a Conceptual Framework for Sustainable Urban Development, SKL International:Stockholm, 2012. 
[24] International Longevity Centre UK, Building our Futures: Meeting the Housing Needs of an Ageing Population, London, 2006.

[25] Naylor, M.D., Hirschman, K.B., Hanlon, A.L., Abbott, K.M., Bowles, K.H., Foust, J., Shah, S. \& Zubritsky, C., Factors associated with changes in perceived quality of life among elderly recipients of long-term services and supports. Journal of the American Medical Directors Association, 17(1), pp. 44-52, 2016.

http://dx.doi.org/10.1016/j.jamda.2015.07.019

[26] Sun, W., Aodeng, S., Tanimoto, Y., Watanabe, M., Han, J., Wang, B., Yu, L. \& Kono, K., Quality of life (QOL) of the community-dwelling elderly and associated factors: A population-based study in urban areas of China. Archives of Gerontology and Geriatrics, 60(2), pp. 311-316, 2015.

http://dx.doi.org/10.1016/j.archger.2014.12.002

[27] Yung, E.H.K., Conejos, S. \& Chan, E.H.W.,Social needs of the elderly and active aging in public open spaces in urban renewal.Cities, 52, pp. 114-122, 2016. http://dx.doi.org/10.1016/j.cities.2015.11.022

[28] Cumo, F., Astiaso Garcia, D., Calcagnini, L., Rosa, F. \& Sferra, A.S., Urban policies and sustainable energy management. Sustainable Cities and Society, 4, pp. 29-34, 2012. http://dx.doi.org/10.1016/j.scs.2012.03.003

[29] Astiaso Garcia, D., Cumo, F., Giustini, F., Pennacchia, E. \& Fogheri, A.M., Ecoarchitecture and sustainable mobility: an integrated approach in Ladispoli town. WIT Transactions on the Built Environment, 142, pp. 59-68, 2014. http://dx.doi.org/10.2495/ARC140061

[30] Astiaso Garcia, D., Cumo, F., Pennacchia, E. \& Sforzini, V., A sustainable requalification of bracciano lake waterfront in Trevignano Romano. International Journal of Sustainable Development and Planning,10(2), pp. 155-164, 2015. http://dx.doi.org/10.2495/SDP-V10-N2-155-164

[31] Cumo, F., Astiaso Garcia, D., Stefanini, V. \& Tiberi, M., Technologies and strategies to design sustainable tourist accommodations in areas of high environmental value not connected to the electricity grid. International Journal of Sustainable Development and Planning, 10(1), pp. 20-28, 2015.

http://dx.doi.org/10.2495/SDP-V10-N1-20-28

[32] Bruschi, D., Astiaso Garcia, D., Gugliermetti, F. \& Cumo, F., Characterizing the fragmentation level of Italian's National Parks due to transportation infrastructures. Transportation Research Part D: Transport and Environment, 36, pp. 18-28, 2015. http://dx.doi.org/10.1016/j.trd.2015.02.006

[33] Astiaso Garcia, D., Bruschi, D., Cinquepalmi, F. \& Cumo, F., An estimation of urban fragmentation of natural habitats: Case studies of the 24 italian national parks.Chemical Engineering Transactions, 32, pp. 49-54, 2013.

[34] Feldman, P.H. \& Oberlink, M., The advantage initiative:developing community indicators to promote the health and well being of older people. Family \& Community Health, 26, pp. 268-274, 2003. http://dx.doi.org/10.1097/00003727-200310000-00004

[35] Diener, E. \& Suh, E., Measuring quality of life: economic, social, and subjective indicators. Social Indicators Research, 40, pp. 189-216, 1997. http://dx.doi.org/10.1023/A:1006859511756

[36] Brown, R.J.\&Brown, I., The application of quality of life. Journal of Intellectual Disability Research, 49(10), pp. 718-727, 2005.

http://dx.doi.org/10.1111/j.1365-2788.2005.00740.x 
[37] Gregory, D., Johnston, R.\&Pratt, G. (eds), Quality of life. In Dictionary of Human Geography, Wiley-Blackwell:Oxford, 2009.

[38] Mohit, M.A., Quality of life in natural and built environment -an introductory analysis. AMER International Conference on Quality of Life 2013, Procedia - Social and Behavioral Sciences, 101, pp. 33-43, 2013.

http://dx.doi.org/10.1016/j.sbspro.2013.07.176

[39] Guidi, G., Gugliermetti, F., Astiaso Garcia, D. \& Violante, A.C., Influence of environmental, economic and social factors on a site selection index methodology for a technological centre for radioactive waste management. Chemical Engineering Transactions, 18, pp. 505-510, 2009.

[40] Tuttitalia.it Statistiche Demografiche, Struttura della popolazione dal 2002 al 2015, available at: http://www.tuttitalia.it/statistiche/indici-demografici-struttura-popolazione/

[41] Cumo, F., Di Matteo, U. \& Rosso, M., Predisposizione di una scheda tecnica per la valutazionepreliminare delle condizioni di sicurezza dei lavoratori e dei fruitori degli ambienti espositivi. Acts of the $61^{\circ}$ Congresso Nazionale della Associazione Termotecnica Italiana, I, 2006.

[42] Astiaso Garcia, D., Cinquepalmi, F. \& Cumo, F., Air quality in Italian small harbours: A proposed assessment methodology. Rendiconti Lincei, 24(4), pp. 309-318, 2013. http://dx.doi.org/10.1007/s12210-013-0254-0

[43] Astiaso Garcia, D., Cumo, F., Gugliermetti, F. \& Rosa, F., Hazardous and noxious substances (HNS) risk assessment along the Italian coastline. Chemical Engineering Transactions, 32, pp. 115-120, 2013.

[44] De Santoli, L., Cumo, F., Astiaso Garcia, D. \& Bruschi, D., Coastal and marine impact assessment for the development of an oil spill contingency plan: The case study of the east coast of Sicily. WIT Transactions on Ecology and the Environment, 149, pp. 185-196, 2011. http://dx.doi.org/10.2495/cp110241

[45] Cumo, F., Cinquepalmi, F. \& Astiaso Garcia, D., Data gathering guidelines for the mapping of environmental sensitivity to oil spill of the Italian coastlines. WIT Transactions on the Built Environment, 99, pp. 119-125, 2008. http://dx.doi.org/10.2495/CENV080111

[46] De Santoli, L., Astiaso Garcia, D. \& Violante, A.C., Planning of flood defence management and rehabilitation of the natural habitat in the downstream part of the river Tiber. WIT Transactions on the Built Environment, 100, pp. 25-34, 2008. http://dx.doi.org/10.2495/GEO080031

[47] Gugliermetti, F., Cinquepalmi, F. \& Astiaso Garcia, D., The use of environmental sensitivity indices (ESI) maps for the evaluation of oil spill risk in Mediterranean coastlines and coastal waters. WIT Transactions on Ecology and the Environment, 102, pp. 593-600, 2007.

http://dx.doi.org/10.2495/sdp070572

[48] Il Sole 24ore, IPR Marketing, Dossier sulla Qualità della vita 2007, available at: http://www2.iprmarketing.it/file/dossier\%20qualitt\%20vita\%202007\%20-\%20il\%20 sentiment\%20ipr.pdf

[49] Beard, J.R. \& Petitot, C., Ageing and urbanization: Can cities be designed to foster active ageing? Public Health Reviews, 32, pp. 427-450, 2010. 